Volume 28, 2018

http://journals.sfu.ca/cjsdw

Special Section Editorial

\title{
Introduction: Play, Visual strategies and Innovative Approaches to Graduate Student Writing Development
}

Brittany Amell

School of Linguistics and Language Studies, Carleton University

Cecile Badenhorst ${ }^{2}$

Education, Memorial University

\section{Abstract}

We begin by introducing the special section of the Canadian Journal for Studies in Discourse and Writing/Rédactologie on play, visual strategies and innovative approaches to graduate student writing development. Most exciting for us as editors of this special section is to see how many authors from various locales are drawing on creative methods, signalling to us that in some ways this is a burgeoning area. We have papers from Germany, the U.K., Thailand, and at least three provinces in Canada. We have some poetry, examples of collages, photos of cats, shapes, and Lego ${ }^{\mathrm{TM}}$. We include the abstracts for each of the papers.

\section{Introduction}

Writing occupies a prominent place in graduate students' academic careers since it is one of the primary tools for assessment and for distributing knowledge. Recognising this, there are increasing calls for more research focused on initiatives and pedagogies that support the writing development of graduate students (Badenhorst \& Guerin, 2016). In this special section of the Canadian Journal for Studies in Discourse and Writing/Rédactologie we respond to that call.

We recognize that many students find writing challenging (see Figure 1), and we hope to turn the focus on a particular range of activities and interventions that address student needs. For this special 
Volume 28, 2018

http://journals.sfu.ca/cjsdw

section, we invited submissions on playfulness, visual strategies, and alternative or innovative approaches to graduate student writing development.

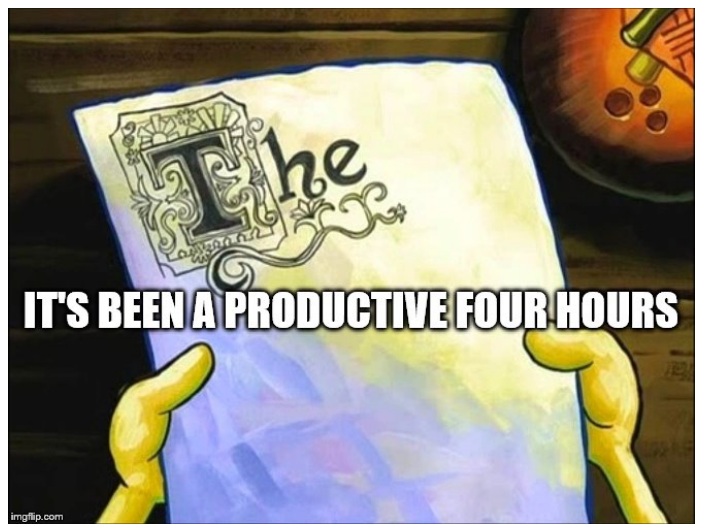

Figure 1. "Writing my thesis..." (meme generated by Brittany)

In particular, we asked for authors to respond to any of the following questions:

- What alternative or innovative pedagogies inspire graduate students to think deeply about their research and to write with confidence?

- How might playfulness, visual strategies and alternative or innovative approaches be important for graduate student writing development?

- What are some challenges with using playful or visual approaches to engaging with writing/stumbling blocks? What are some successes?

- What strategies or tactics do supervisors, writing centre tutors or teaching assistants use to support post/graduate students with navigating stuck places?

- While there is a sense that space is important in the pedagogies of research writing literature, how space is conceptualised and applied in the research writing literature is limited. As such, how might an understanding of liminal writing spaces be informed by theories of place, space, and embodiment?

\section{Why the Focus on Play, Visual and Innovative Approaches?}

We were moved to focus on play, visual, and innovative approaches because we wanted to: 1) move the conversation away from a focus on (a lack of) discipline or work ethic and the need for "bootcamps" that encourage notions of student deficit; 2) to shift thinking from writing as inevitably 
Volume 28, 2018

http://journals.sfu.ca/cjsdw

a site of struggle to one where graduate students might find enjoyment, satisfaction, and growing self-efficacy in their writing practices; and 3) encourage students to leave behind their places of comfort and embrace new ways of thinking about their writing.

We chose this particular focus because we see play, visual and innovative approaches as meaningful ways to engage with the intangible nature that often accompanies graduate writing and research. A growing body of research suggests that invoking a sense of playfulness towards one's writing practice may provide students with tools to navigate through difficultly to meaningful understanding (Davies Turner \& Turner, 2016; Badenhorst, Moloney, Rosales \& Dyer, 2012; Kiley, 2009). Play allows exploratory practice where one can deliberately use mystery, puzzlement, and dilemma.

Ulmer (2017) describes writing as a site of creative intervention. She views alternative ways of engaging with writing as not being unproductive but a way of being differently productive. Playful, visual, and innovative strategies are ways of being differently productive. Through play we search for presence of ideas, ourselves, our writing. We employ ambiguity, uncertainty, incomplete thoughts, and acknowledge that the process of writing can be enticing and intangible, part external incorporation of texts, but also internal processes related to memory and personal uniqueness.

We see these approaches as valuable in that they can encourage graduate students to engage in the fluidity and ambiguity of thoughts and ideas. Although feeling stuck in one's writing and research can be disorienting and distressing (Humphrey \& Simpson, 2012; Kiley 2009; Kiley \& Wisker, 2009), in small doses, it is also a necessary aspect of writing and research. Lather (2007) argues that sometimes, the process of learning to navigate periods of feeling stuck or lost is a valuable yet often overlooked process. Graduate students can benefit from this normalization of being stuck and lost. Since playful and innovative approaches often employ the deliberate use of ambiguity, these approaches may also emphasize for students that the process of finding their way is a necessary path on the journey toward meaningful understanding.

Perhaps most exciting for us to see as editors of this special section is how many authors from various locales are drawing on creative methods, signalling to us that in some ways this is a burgeoning area. We have papers from Germany, the U.K., Thailand, and at least three provinces in Canada. We have some poetry, examples of collages, photos of cats, shapes, and Lego ${ }^{\mathrm{TM}}$. What each of these papers show in their own way is the value of alternative approaches that focus on deep, meaningful approaches to writing. We hope this special section will incite interest and curiosity from researchers and practitioners alike. 
Volume 28, 2018

http://journals.sfu.ca/cjsdw

\section{Overview of the Special Section}

Brittany Amell \& Eve-Marie Blouin-Hudon lead the special section with a discussion around key concepts they consider to be foundational to playful and creative methods: play, playspace and mindsets. Building on these concepts, they offer some remarks about the ambivalence some learners may have-which they refer to as play ambivalence-and propose that this ambivalence is partly related to the three concepts underscored in this article. They suggest that future research in play and graduate writing development could better consider this play ambivalence.

In her essay, Nancy Bray describes how she experienced difficulties when writing in particular academic genres. Finding spaces to play in these genres helped her to ease these difficulties and to negotiate the conflicts and contradictions of the academy. To explore and explain innovative spaces within genres, she extends Deleuze and Guattari's notion of smooth and striated spaces and ties it to work in rhetorical genre studies. Opening smooth spaces in striated academic genres, she concludes, is not only important for students like herself, but may also help all of us better respond to the changing realities of graduate studies and academic work in Canada.

Katrin Girgensohn \& Felicitas Macgilchrist, in their paper, present a program for a university writing group, trialled in Germany, that differs from many writing groups in that writers were allowed high levels of autonomy and choice. They drew on French philosopher Jacques Rancière and his presupposition of a radical equality of intelligence to theoretically frame this writing group model. They suggest that these writing groups provide a foundation for students to experience academic writing in ways that are more playful, creative and joyful, and with less feelings of interiority and more awareness of their own intelligence, capacity, and creativity. The paper outlines how this program could be relevant for writing educators, curriculum developers, and other faculty at higher education institutions across global contexts.

Cecile Badenhorst raises questions about engaging in play. She argues that while playfulness is important to graduate writing to shift students into new ways of thinking about their research, a key obstacle to having fun is writing anxiety. Writing is emotional, and despite a growing field of research that attests to this, emotions are often not explicitly recognized as part of the graduate student writing journey. She argues that many students experience writing anxiety, particularly when receiving feedback and that this is crucial to meeting disciplinary expectations and developing a scholarly identity for the writer. Yet, she suggests, many students are unable to cope with the emotions generated by criticism of their writing. This paper presents pedagogical strategies-free- 
Volume 28, 2018

http://journals.sfu.ca/cjsdw

writing, negotiating negative internal dialogue, and using objects to externalize feelings-to help students navigate their emotions, while recognizing the broader discursive context within which graduate writing takes place. These pedagogical strategies help students to recognize their emotions, to make decisions about their emotional reactions, and to develop agency in the way they respond to critical feedback. By acknowledging the emotional nature of writing, she contends, students are more open to creativity, originality, and imagination.

James Burford, Adisorn Juntrasook. Wasana Sriprachya-anunt, and Linda Yeh explore an underresearch area of writing studies - the use of contemplative pedagogies in graduate writing in the context of Thailand. Drawing on reflective analysis from writing instructors, their article seeks to both contextualize the teaching and learning of writing in the Thai context, and to introduce experiments in contemplative writing pedagogy. In particular, the article reports on graduate-level writing courses that are embedded within the curricula of two education-field Masters programmes in Thailand. Four instructors involved in these courses reflect on their combined experience of integrating contemplative pedagogies, describing the steps they undertook to bring these into the classroom. The contribution of this study is its reporting on research in the under-considered area of contemplative practices, as well as opening up the consideration of graduate writing development in non-Anglophone contexts, such as Thailand. By providing the tools and strategies used by Thai instructors they hope to will assist others to bring contemplative approaches into play in their own classrooms.

Zoe Jones \& Nonia Williams explore the use of four playful and alternative strategies that aim to free-up and inspire graduate writers. These strategies are their use of shape cards, LEGO®, walking tutorials, as well as yoga and meditation. Through a combination of reflection on experience, initial primary research, and engagement with wider discussion, they demonstrate the benefits and joys of our creative and innovative writing support work. They also acknowledge that such techniques involve risks and challenges, and do not suit every graduate writer-as one of their students put it, "I am done with toys!" Nevertheless, this article demonstrates that the potential these practices have to support, empower, and deepen graduate student writing.

Sandra Abegglen, Tom Burns, and Sandra Sinfield present a case study that illustrates what happened when they took a playful approach in a first-year undergraduate academic skills module and a graduate facilitating student learning module. They asked their students to "draw to learn." They found that students not only enjoyed the challenges set for them but students also "blossomed," and approached their academic writing with more confidence and joy. They argue for a more ludic 
Volume 28, 2018

http://journals.sfu.ca/cjsdw

approach to learning and teaching in Higher Education to enable Widening Participation students and their tutors to become the academic writers they want to be. In particular, they suggest that "blind drawing" is a powerful tool for diminishing the fear of failure and for fostering deep understanding and self-confidence.

Andrea Olinger ends the special section by presenting and reflecting on a found poem she composed from the final papers of students in her multidisciplinary graduate writing class. She invites readers to create their own found poems to experience the delight she felt.

\section{Final Words}

We would like to extend our gratitude to the authors and reviewers involved in doing much of the invisible work to produce this special section. We appreciate your collegiality and the generosity of your time and energy. It was wonderful to work with all of you. We also extend our thanks to Chinwe Ogolo who provided graduate assistance to this project. To Sibo Chen and Joel Heng Hartse, Journal Editors, thank-you for providing such solid support in helping us to negotiate the complexities and mechanics of the online system, as well as the editing process as a whole. We appreciate the care you extended to us. As co-editors of this special section, we have also enjoyed working with and learning from each other. We hope readers enjoy this section as much as we have enjoyed compiling it.

\section{Endnotes}

1. Correspondence may be addressed to Brittany.Amell@Carleton.ca.

2. Correspondence may be addressed to Cbadenhorst@mun.ca. 
Volume 28, 2018

http://journals.sfu.ca/cjsdw

\section{References}

Badenhorst, C., Moloney, C., Rosales, J., Dyer, J. (2012). Graduate research writing: A pedagogy of possibility. LEARNing Landscapes, 6(1), 63-80.

Badenhorst, C.M. \& Guerin, C. (2016). Introduction: Post/graduate writing pedagogies and research literacies. In C.M. Badenhorst \& C. Guerin (Eds.), (2016). Post/graduate writing pedagogies and research literacies (pp. 3-28). Amsterdam: Brill/Emerald Publishing.

Badenhorst, C., Moloney, C., Rosales, J., \& Dyer, J. (2012). Graduate research writing: A pedagogy of possibility. LEARNing Landscapes, 6(1), 63-80. Retrieved from: http://learninglandscapes.ca/index.php/learnland/article/view/576

Davies Turner, M. \& Turner, J. (2015). Play and creativity in academic writing. In C. Badenhorst \& C. Guerin (Eds.), Studies in writing: Research literacies and writing pedagogies for masters and doctoral writers (pp. 356-370). Leiden, NL: Brill.

Humphrey, R., \& Simpson, B. (2012). Writes of passage: Writing up qualitative data as a threshold concept in doctoral research. Teaching in higher education, 6(17), 735-746.

Kiley, M. (2009). Identifying threshold concepts and proposing strategies to support doctoral candidates. Innovations in Education and Teaching International, 46(3), 293-304. doi:10.1080/14703290903069001

Kiley, M., \& Wisker, G. (2009). Threshold concepts in research education and evidence of threshold crossing. Higher Education Research \& Development, 28(4), 431-441.

doi:10.1080/07294360903067930

Lather, P. (2007). Getting Lost. Albany, NY, USA: State of New York Press.

Ulmer, J., (2017). Writing slow ontology. Qualitative Inquiry, 23(3), 201-211. 